
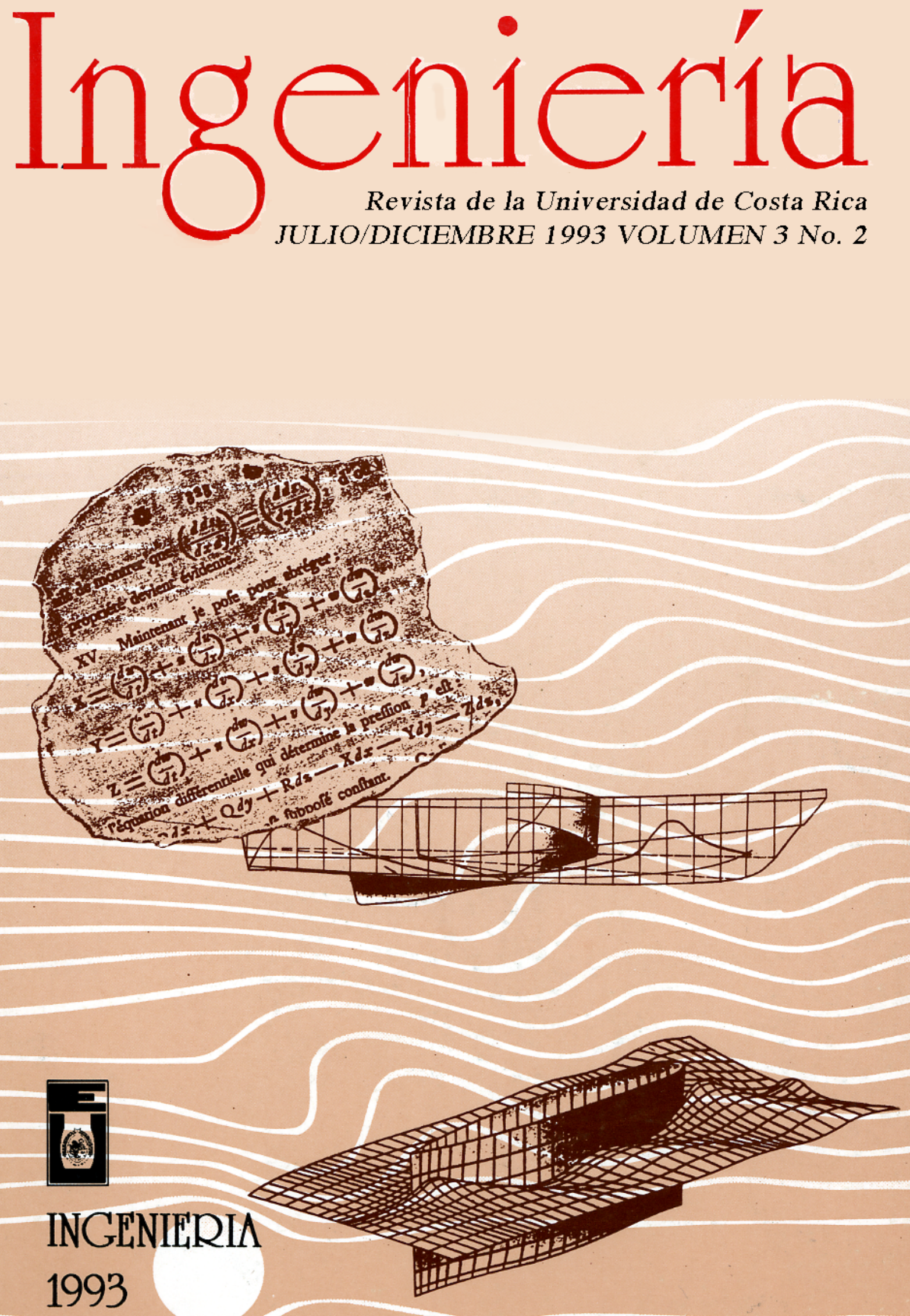


\title{
SOLID WASTE RECYCLING IN COSTA RICA: BALANCE AND PERSPECTIVES ${ }^{1}$
}

\author{
Rosendo Pujol and Eric Solano ${ }^{2}$
}

\begin{abstract}
Resumen
Reciclaje en Costa Rica: Balance y perspectivas.

Este artículo explora las realidades del reciclaje en Costa Rica, así como su evolución es los últimos años. Se concentra en evaluar los flujos de materiales y los aspectos económicos de dos productos: papel y vidrio. Brevemente evalúa los mismos aspectos para el plástico y el acero. Costa Rica muestra las siguientes tasas de recuperación: para papel, 22.2\% y para vidrio, $15.5 \%$. Hay tres factores que dificultan el mejoramiento de estas tasas de recuperación: a) ingresos per-cápita crecientes, b) poca educación ambiental en las clases alta y media y c) políticas de companías grandes y pequeñas, que consisten en la promoción de materiales de envasado, no reutilizables, y en algunos casos difíciles de reciclar.
\end{abstract}

El reciclaje muestra una estructura económica compleja: recolectores informales de la calle, pocos intermediarios con grandes márgenes de utilidad y una compañía por cada tipo de producto reciclable, la cual tiene el monopolio de la compra. Los mercados para productos reciclables no trabajan adecuadamente.

Costa Rica tiene tres desafíos simultáneos: incrementar las tasas de recuperación, desarrollar mercados para productos reciclables y mejorar el nivel de vida de los recolectores callejeros. Para enfrentar estos retos, se requiere la ayuda del Estado y de las Organizaciones no Gubernamentales.

\section{Summary}

This paper explores the Costa Rican recycling realities and its evolution over the last years. It concentrates in evaluating the materials flows and economics of two products: paper and glass. It briefly evaluates plastic and steel. Costa Rica shows recovery rates for paper $(22.2 \%)$ and glass $(15.5 \%)$. Three factors make difficult to improve recovery rates: a) growing per-capita income, b) an upper and middle classes very uneducated environmentally and c) the policies of big and small companies promoting non-reusable and in some cases not easily recyclable packaging and bottling materials. Recycling shows a complex economic structure: informal street collectors, few consolidators with big profit margins and a company with monopsony buying power for each recyclable product. The markets for recyclables are not working properly.

Costa Rica has three simultaneous challenges: increase recovery rates, develop markets for recyclables and improve the social and economic status of the street collectors. To confront these issues will require intervention from the State on non-governmental organizations.

A preliminary version of this paper was presented in the International Conference on Solid Waste Management and Secondary Materials, November 15 18, 1992, Philadelphia.

2 Rosendo Pujol is Associate Profesor and Director of the Urban Sustainable Development Research Program. Eric Solano is researcher with the same group. Both teach at the Civil Engineering School of the University of Costa Rica

\section{INTRODUCTION}

\section{General Elements}

Solid waste has become a hot issue in Costa Rica. The landfills are not handled adequately, much solid waste is not being disposed properly, and people are becoming impatient with 
the problem. Many communities try desperately to find new solutions. Politicians are searching to privatize the operation not only in search for efficiency or effectiveness, but also in order to avoid the "political dangers" of solid waste problems.

As in the rest of the world, to confront the solid waste crisis will require of multiple solutions. Recycling is an important part of any package. It is not a new practice,... it is in fact an "old wine", but changes within the country and international realities are forcing to use.... "new bottles" for some old and new solutions.

This paper is a first step in the understanding of the macroeconomic and social meaning of recycling based on microeconomic facts. The results presented are preliminary, but give good clues about solid waste recycling in Costa Rica.

\section{A. BASIC COSTA RICAN REALITIES}

Costa Rica is a very small country $(51000$ $\mathrm{km} 2$ ) with a population of more than 3 million. It is very centralized spatially and institutionally. The capital city San José and other smaller cities around conform the only metropolitan region of the country, the Great Metropolitan Region of San José (GMRSJ) with more than 1 million inhabitants.

The medium annual per capita income was equivalent to US\$1780 dollars in 1989. Open unemployment is only $4.1 \%$. Costa Rica has narrowed effective social differences through the existence of public services and infrastructure. The country has reached high levels of social development: education, health, electrification, and running water supply.

The Costa Rican economy is based in tourism and the agroindustry: banana and coffee in particular: Other export products are flowers, fruits, shrimp, and garments. All these activities generate solid wastes and need packaging materials. The growing importance of ecotourism has made the proper management of solid wastes even more important in order to preserve the Costa $\mathrm{Ri}$ can image of an ecologically enlighten country.

Heavy industry is almost non-existent. This limits the generation of hazardous waste within the country. Two factories use recycled materials, one in the production of toilet paper and the other in the production of glass containers, and very soon a kraft paper mill and a plastic product's company will start processing recyclables.

\section{B. BASIC ELEMENTS OF THE SOLID WASTE SITUATION IN COSTA RICA}

Empiricism characterizes solid waste's handling in Costa Rica. Most solid waste comes from agriculture and agroindustry, but it will not be discussed here. There is an inadecuate handling of hazardous materials. They are not incinerated and many officals try to ignore the problem.

Recycling and reuse are common, which lowers the generation rates and decreases the proportion of recyclables in the municipal solid waste.

There is one big landfill for the Great Metropolitan Area of San Jose. It can not be called "sanitary landfill" because the municipal government of San Jose does not operate it adecuately, mainly because bureaucratic restrictions. Even more serious are the domestic, commercial and industrial waste that do not go to any landfill. Most of the non-accounted waste ends up in Costa $\mathrm{Ri}$ can rivers.

Government officials have gone through several cycles of indifference and emergency declarations. But many local politicians would like to eliminate completely the problem from their agendas and that has been a very powerful factor in the rush to privatize, as much as possible, solid waste management in the following months.

The National Waste Management Plan (Plan Nacional de Manejo de Desechos-PNMD) is a very good overall diagnostic about waste managemnt problems in Costa Rica. It was developed by a group of Costa Rican professionals with the help of the German Agency GTZ during 1991. Among many other things the PNMD recommends to increase recycling.

Tha markets for recyclable materials are not very developed in Costa Rica. There is almost no competition and big profit margins. Table 1 indicates some current prices for recyclable materials. Significant are the very low prices for mixed paper $\$ 18 /$ ton and for mixed glass $\$ 3 /$ ton.

There is also some information about quantities and composition of solid waste in Costa Rica. Both reveal differences compared to developed countries. Generation of residential waste is lower (see Table 2), and the composition is quite different with much higher proportion of food residues (see Table 3).

The proportion by weight of recyclables materials in Costa Rica is much lower than in the United States. There are also important differences 
Table 1

Market prices for recyclables materials

\begin{tabular}{cccc}
\hline Material & $\begin{array}{c}\text { Price offered by final } \\
\text { users of recyclables } \\
\text { materials (A) }\end{array}$ & $\begin{array}{c}\text { Price offered by } \\
\text { Consolidators }\end{array}$ & $\begin{array}{c}\text { Gross Profit } \\
\text { Margin }\end{array}$ \\
\hline
\end{tabular}

I. Paper

Scott paper company

1.1. Computer

1.2. Without ink

1.3. One side printed

1.4. Newspaper

1.5. Both sides printed

1.6. Mixed

2. Ricalit Company

1.7. Newpaper

2. Glass

2.1 Class A: Clean and classified with $10 \%$ of impurities

2.2 Class B: Color classified with more than $10 \%$ of impurities

2.3 Class C: Mixed

2.4 Class D: Window glass

3. Plastics

3.1 Mixed and clean

\section{Metals}

4.1. Steel

4.2. Copper

4.3. Aluminum

4.4. Bronze

4.5 Lead (Batteries)

$\$ 190 /$ ton
$\$ 190 /$ ton
$\$ 154 /$ ton
$\$ 95 /$ ton
$\$ 81 /$ ton
-
$\$ 102 /$ ton
$\$ 107 /$ ton (clean)

$\$ 107 /$ ton (clean)

$\begin{array}{llr}\$ 30 / \text { ton } & \$ 7 / \text { ton } & 329 \% \\ \$ 24 / \text { ton } & \$ 3 / \text { ton } & 700 \% \\ & & \\ \$ 14.5 / \text { ton } & \$ 3 / \text { ton } & 383 \% \\ \$ 24 / \text { ton } & \$ 7 / \text { ton } & 243 \%\end{array}$

$\$ 0.07 / \mathrm{kg}-\$ 0.18 / \mathrm{kg} \quad$ Not now. One will start soon

Consolidator

exports the

$\$ 110 /$ ton
$\$ 73 /$ ton
$\$ 73 /$ ton
$\$ 73 /$ ton
$\$ 73 /$ ton
$\$ 18 /$ ton

$73 \%$

$60 \%$

$111 \%$

$30 \%$

$11 \%$
$\$ 275 /$ ton

$\$ 900 /$ ton

\$350/ton-\$470/ton

$\$ 630 /$ ton-\$745/ton

\$390/ton-\$470/ton

Table 2

Solid waste generation in Costa Rica (1990)

\begin{tabular}{|c|c|c|c|c|c|}
\hline \multirow{2}{*}{$\begin{array}{l}\text { Area } \\
\text { Pour mean cities within } \\
\text { The great metropoitan region }\end{array}$} & \multicolumn{2}{|c|}{$\begin{array}{l}\text { Per capita generation } \\
\text { (KG per capita per day) }\end{array}$} & \multicolumn{2}{|c|}{$\begin{array}{l}\text { Population } \\
\text { Urban/Rural }\end{array}$} & \multirow{2}{*}{$\begin{array}{c}\text { Estimated total } \\
\text { Quantity (Tons per day) } \\
440.7(31.6 \%)\end{array}$} \\
\hline & 0.8 & 0.5 & 431239 & 191367 & \\
\hline $\begin{array}{l}\text { Rest of the Great metropolitan } \\
\text { region of San Jose }\end{array}$ & 0.5 & 0.4 & 607865 & 427299 & $474.8(34.0 \%)$ \\
\hline $\begin{array}{l}\text { Other Towns } \\
\text { Rest of the country }\end{array}$ & $\begin{array}{l}0.4 \\
0.3\end{array}$ & $\begin{array}{l}0.4 \\
0.3\end{array}$ & $\begin{array}{l}202977 \\
107494\end{array}$ & $\begin{array}{l}527745 \\
518610\end{array}$ & $\begin{array}{l}292.3(20.9 \%) \\
187.8(13.5 \%)\end{array}$ \\
\hline Totals & - & - & 1349576 & 1665020 & $1395.6(100 \%)$ \\
\hline
\end{tabular}


Table 3

Residential solid waste composition in Costa Rica (By weight)

\begin{tabular}{|c|c|c|c|c|}
\hline \multirow[t]{2}{*}{ Material } & $\begin{array}{l}\text { Río azul Landfill (l). } \\
\text { (Composition for the Great } \\
\text { Metropolitan Region) }\end{array}$ & $\begin{array}{c}\text { Rural coastal town of } \\
\text { Quepos (2) }\end{array}$ & $\begin{array}{l}\text { Sarapiqui } \\
\text { County (3) }\end{array}$ & $\begin{array}{l}\text { U.S.A. } \\
\text { (4) }\end{array}$ \\
\hline & \multicolumn{4}{|c|}{ Composition for the rest of the country } \\
\hline Organics & $62.1 \%$ & $70.2 \%$ & $72.7 \%$ & $25.0 \%$ \\
\hline Paper and kraft paper & $17.9 \%$ & $7.7 \%$ & $5.0 \%$ & $40.0 \%$ \\
\hline Wood & $1.3 \%$ & - & - & - \\
\hline Plastic & $5.6 \%$ & $8.5 \%$ & $12.5 \%$ & $8.0 \%$ \\
\hline Metal & $1.4 \%$ & $2.4 \%$ & $2.4 \%$ & $8.5 \%$ \\
\hline Glass & $7.0 \%$ & $2.9 \%$ & $3.2 \%$ & $7.0 \%$ \\
\hline Inert materials: Debris and soil & $4.7 \%$ & - & - & - \\
\hline Others & & $8.3 \%$ & $4.2 \%$ & $11.5 \%$ \\
\hline Total & $100.0 \%$ & $100.0 \%$ & $100.0 \%$ & $100.0 \%$ \\
\hline
\end{tabular}

(1) Instituto Costarricense de Electricidad y Electrowatt Eng. Services Ltd. "Non conventional Energy Sources, Vol III, Incineration and Biomass", december, 1983.

(2) Asociación pro conservación Acuática. "Proyecto de manejo de desechos sólidos en el Cantón de Aguirre", september, 1992. Quepos is the main town and important turism attractor.

(3) Minor González. Paquetes tecnológicos de manejo de desechos sólidos para ciudades pequeñas. Tesis de grado en Ingeniería Civil, Universidad de Costa Rica.

(4) U.S. Environmenal Protection Agency. Municipal Solid Waste Composition, 1988.

Table 4

Solid waste total quantities by material (Tons per day)

\begin{tabular}{|c|c|c|c|c|}
\hline Matrial & Great metroplitan región & Rest of the country & Total Generated & $\begin{array}{l}\text { Total Recovered } \\
\text { from waste stream }\end{array}$ \\
\hline Organics & $\begin{array}{l}568.5 c ̧ \\
(62.1 \%)\end{array}$ & $\begin{array}{l}337 \\
(70.2 \%)\end{array}$ & 905.5 &. \\
\hline Paper and kraft & $\begin{array}{l}163.9 \\
(17.9 \%)\end{array}$ & $\begin{array}{l}37.0 \\
(7.7 \%)\end{array}$ & 200.9 & 50 \\
\hline Wood & $\begin{array}{l}11.9 \\
(1.3 \%)\end{array}$ & - & 11.9 & \\
\hline Plastic & $\begin{array}{l}51.3 \\
(5.6 \%)\end{array}$ & $\begin{array}{l}40.8 \\
(8.5 \%)\end{array}$ & 92.1 & \\
\hline Metals & $\begin{array}{l}12.8 \\
(1.4 \%)\end{array}$ & $\begin{array}{l}11.5 \\
(2.4 \%)\end{array}$ & 24.3 & \\
\hline Glass & $\begin{array}{l}64.1 \\
(7.0 \%)\end{array}$ & $\begin{array}{l}13.9 \\
(2.9 \%)\end{array}$ & 78.0 & 14.5 \\
\hline Inert Materials & $\begin{array}{l}43.0 \\
(4.7 \%)\end{array}$ & - & 43.0 & \\
\hline Others & & 39.8 & & 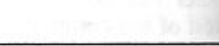 \\
\hline Total & 915.5 & 480.1 & 1395.6 & \\
\hline
\end{tabular}


Table 5

Percenteage of recovered materials by weight

\begin{tabular}{|c|c|c|c|c|}
\hline & rial & $\begin{array}{l}\text { Included in municipal } \\
\text { solid wast: } T\end{array}$ & $\begin{array}{l}\text { Recovered from waste } \\
\text { Stream: } \mathbf{R}\end{array}$ & $\begin{array}{c}\text { Percent recovered } \\
R /(T+R)\end{array}$ \\
\hline 1. & $\begin{array}{l}\text { Paper and } \\
\text { kraft paper }\end{array}$ & $\begin{array}{c}194.4 \text { Ton/Day } * 365= \\
70956 \text { Ton/Year }\end{array}$ & $\begin{array}{c}55.33 \text { Ton/Day *365 = } \\
20195 \text { Ton/Year }\end{array}$ & $22.2 \%$ \\
\hline 2. & Glass & $\begin{array}{c}78.7 \text { Tony/Day }= \\
28725 / \text { Year }\end{array}$ & $\begin{array}{c}\text { 14.5 Ton/Dat } * 365= \\
5293 \text { Ton/Year }\end{array}$ & $15.5 \%$ \\
\hline
\end{tabular}

within the country. Paper and kraft-paper represents $17.9 \%$ in San José but only $7.7 \%$ in Quepos and $5 \%$ in Sarapiquí. Glass is $5.6 \%$ of the waste stream in San José, $2.9 \%$ in Quepos and $3.2 \%$ in Sarapiquí. Plastic items are $5.6 \%$ in San José, 8.5 $\%$ in Quepos and $12.5 \%$ in Sarapiquí.

\section{Some conclusions about recycling and waste} flows in Costa Rica

Table 4 presents a brief calculation of how much materials go into the waste stream in Costa Rica in order to determine upper boundaries to any recycling effort. Table 5 computes approximately Costa Rican recovery rates. The results indicate $15.5 \%$ of the glass and $22.2 \%$ of the paper entering into the solid waste stream are recovered. These figures are underestimating reality because there are many other buyers not included in the calculations.

It is obvious that total recovery is impossible but there are many possibilities to increase recovery rates. The increments will be function of the demand for recyclables, in particular the acceptance for mixed and not first class recyclables; and second, the effectiveness with which materials will be cleaned and separated.

These figures do not reveal the essential component of the Costa Rican recycling tradition of reusing and fixing all kinds of products. This realities explain partially the low figures for plastic, paper, textiles in the Costa Rican composition analysis of municipal solid waste.

\section{THE COSTA RICAN RECYCLING REALITY}

This section analyses several recyclables products, in particular paper and glass.

\section{A. ESSENTIAL ELEMENTS OF PAPER AND PLASTIC RECYCLING}

\section{Paper and cardboard}

The Scott Paper Company is right now the only industrial producer of paper in Costa Rica. Only $30 \%$ of its raw materials are virgin pulp. This company recycles 1200 tones of paper per month collected in Costa Rica which represent $60 \%$ of its recycled paper needs. The rest comes from the United States. Table 1 indicates quantities and prices of different qualities of recycled paper within Costa Rica.

The paper is bought directly to factories which generate some paper residue and from six major consolidators. The market price for the street collectors or scavengers in the Río Azul landfill wich serves the San Jose Metropolitan Area are much lower than the price paid by the Scott Paper. The paper company does not buy directly from street collectors or even big paper endusers (institutions). Additionally, it seems that the Scott Paper provides capital to the consolidators. In consequence, it could be questioned the real price paid to the consolidators and their independence from the Scott Paper Company.

The economics of cheaper local recycled paper and continuous importation from the United States does not seem consistent with a non-aggressive attitude for more local paper recovery by the Scott Paper. Direct purchases would stimulate a higher rate of recovery from the waste flow, specially because some of the consolidators are rejecting paper.

Some of the potential explanations for this lack of aggressiveness are: a) they are effectively buying most of the recycled paper with the high required quality; b) to increase the recycled paper storage capabilities is too expensive; c) they do not want to deal with small informal collectors; d) 
the existence of "inflated invoices" from products coming from the U.S.A and d) the effective use of their monopsony power, in order to keep local prices low.

RICALIT produces fiber-cement construction materials and buys an estimated of seventy tons per month of recycled newspapers as raw materials. They are paying $\$ 102$ per ton of newspaper and additional $\$ 5$ per ton if it is clean.

In the second semester of 1993, a new kraft paper factory will open in the Santa Ana area and will buy all the cardboard and paper that can be recovered in the Metropolitan Region of San José. The new factory will demand initially less than the 83 tons required daily by the Scott Paper Company. The paper mill will accept lower quality paper and will compete directly with the Scott Paper Company. In fact, they are already storing recycled paper products at least at an estimated daily rate of three tons.

The final result will probably be the Scott Paper buying only the first class paper and the new kraft manufacturing plant buying the rest including all the cardboard. The new kraft-paper mill company plans to create a network of collecting centers which will acquire used paper directly from the street collectors. In consequence, the demand for Costa Rican recycled paper will increase significantly in the following years.

\section{Environmental considerations}

Any recycling effort should be seen as part of a large chain of processes which in some cases have negative impacts. The Scott Paper Plant generates contaminated water outflows and solid waste.

The Scott Paper plant has a primary treatment for its $10000 \mathrm{~m} 3$ of daily outflows. It removes most of the contamination but still the water thrown into the river has an oxygen chemical demand of 427 (mg/liter) and an oxygen biochemical demand of 149 (mg/liter). Even though, this values are far from ideal, they are not bad for Costa Rica, where many industries have bad environmental records. No problem with ink residues has been reported by the Health Ministry.

The paper plant generates 15 tons of paper residues which are disposed of in a private landfill. Research to use them as raw materal for construction products is being made at the University of Costa Rica.
The Costa Rican Health Ministry has been worried with the use of dioxin in the paper mill and the problem is not completely solved yet. On the other hand, the company for many years has promoted with considerable success the non-dyed "Natural" brand. Its success is related mostly to its cheaper price, and not to its "greener character" because in fact, the population has not been educated about the terrible impacts of dioxins. Its selective promotion of the "Natural" brand seems to respond to a profit maximization strategy of market segmentation.

\section{Glass}

In Costa Rica, glass is very common for bottling and packing material. However, there has been a rapid transition from glass toward plastic and paper in different industries among them milk, marmalades, sauces, and vinegar. Non-reusable glass beer containers are not very popular despite that they have been around for a long time.

However, many small producers of wine, vinegar, honey, and sauces continue reusing glass bottles. Glass has been traditionally recovered by informal collectors which buy it directly from homes. More recently two non-profit charitable organizations have started asking for paper and glass donations.

VICESA is the only glass producer in Costa Rica. It competes in Central America with a Guatemalan and a Panamanian factories. It buys separated and mixed glass, some of it broken and some bottles. In 1990 VICESA bought 5230 tons of recycled glass which is $9.6 \%$ of its production. The main suppliers to VICESA are Oscar Estrada a consolidator that provides 7 tons per day, the Coca $\mathrm{C}$ la bottling company ( 5 tons/day). Similar amounts are supply by the Costa Rican beer private monopoly and the Children's Foundation which has $\mathrm{co}^{-}$ llection deposits close to most Costa Rican churches and some supermarkets and crowded places.

\section{B. COMPLEMENTARY ELEMENTS}

\section{Other recyclables}

\section{Plastics}

The market for plastic recyclables is almost non-existent. The main problem is that virgin plastic is cheaper than most recycled material. 
Many street collectors are selling the used plastic containers ( 1 gallon) to small factories which reuse them again. However there is no market yet for used 0.5 and 2 liters soft drinks bottles that have inundated the country for several years.

The Coca Cola Comapany recently introduced the 1.5 liter recoverable plastic bottle. This could be an important step toward a most sustainable development. This recoverable container weights less and cools faster than glass bottles and is not breakable.

In the past, several firms were recycling plastic bags collected by scavengers from the Río Azul landfill, but now there is only one small company buying some plastics and pelletizing them. YAMBER, a producer of plastic bags has decided to star buying plastics for recycling in early 1993.

\section{Iron and Steel}

Old transportation and industrial equipment is the main source of scrap steel in Costa Rica. These recycled products represented approximately $25 \%$ of raw material used in the production of construction steel. That practice has been abandoned probably due to the low international price of steel and the manufacturing complications involved. However, there is a successful scrap steel buyer that exports scrap metals (see table 1).

\section{Aluminum}

Beer and soft-drinks aluminum cans were recently introduced in Costa Rica. The beer company is paying 1 colon, i.e. an equivalent US\$.75 cents for each recovered can. The program can be considered a success, since most of the cans are effectively being recycled. The Children's foundation has located deposits around the country and seems to be successful too. The price set by the company is low enough to have generated competition from local aluminum users which are also buying at similar prices. The market price for aluminum ranges from US\$ 350 to US\$ 470 per ton.

\section{Some setbacks and new efforts}

\section{Some setbacks}

Solid waste issues are very related to local conditions (social, economic, technological) and they determine the institutional and social structure of the recycling activities.

However, the policies generated outside of the country have also great impact: two cases illustrated this point: lower steel price in the international markets help to diminish metal scrap use in Costa Rica; the bottling practices of soft drinks corporations has great impacts (negative or positive) in the size of the solid waste stream in Costa Rica.

\section{Other recent efforts}

There are local efforts on recycling in Goicoechea county, part of the San Jose Metropolitan Area, in two upper-middle class neighborhoods. The efforts have been self-sustaining, but there is not enough information to determine its marginal impact above the traditional recycling occurring there and in the rest of the metropolitan area before. These recycling efforts may have negative impacts: a) destroy the way of living of many poor street collectors or b) lower the price of recyclables at the generating sites. There is no guarantee that those recycling efforts will improve the markets for recyclable materials (more vendors and purchasers).

\section{EVALUATION OF THE SOCIAL AND ECONOMIC STRUCTURE OF THE RECYCLING ACTIVITIES}

\section{Great Costa Rican traditions}

There are many good traditions which diminish considerably the solid waste streams through waste reduction and are not included in recovery rates analysis. Among this practices is important to take notice of the following:

reuse and repair of many products such as clothes, shoes, furniture, constant repair of old cars, household appliances, and industrial machinery because the relatively low labor/equipment cost ratio,

an extended donation tradition of used products (clothes, toys) through church and charitable groups,

- $\quad$ supermarket plastic bags are used to deposit domestic waste, 
organic waste is used as organic fertilizer in flower or vegetable gardens, refills save packaging materials

All these practices help considerably to keep generation of domestic and commercial rates below the levels of industrialized countries and decrease the proportion of recyclables.

\section{Recycling is a pervasive reality}

The municipal crews that collect solid wastes operate their own recycling activities. Besides, informal recycling activities within governmental institutions are performed by janitors. In consequence, it is not clear that additional recycling efforts by government and public institutions will improve recovery rates.

\section{Poverty is a big motivator}

Only very poor people, with little education, but with independent spirit and attitude will work on solid waste street collection and will confront and accept the social stigma still attach to it; the difficult conditions in which street collectors work and live; and the small income.

Any non-governmental organization desiring to improve the conditions of the "poor street collectors" and/or create small cooperatives, will have to deal with this reality and confront the market power of final users and consolidators.

\section{Intermediaries are important}

The intermediaries appear to be earning very big profit margins (see Table 1), but they fulfill an important social role of facilitating the recyclables acquisition for the industrial user. The real issue is if their big mark-ups are justified and necessary. Now, it is unclear if they are more obstacle than a help in the recycling process.

\section{Very imperfect markets}

Still there are not real markets for recycling materials. Monopsonies control the system. Most street collectors lack of capital, knowledge and minimum income necessary to fight for better prices. Nobody is promoting the organizations of the street collectors to increase their bargaining power.
The new kraft paper factory could change dramatically the market for recycled paper, increasing demand, competition, and probably increasing prices paid to the street collectors.

Efficient markets would promote both the reuse and collection of items. Lower end-user prices will promote recycling. Higher prices at the collection side would promote much more intensive recycling and social improvement for the street collectors.

\section{IMPACTS OF RECYCLING IN COSTA RICA}

\section{Impacts the current recycling effort}

\section{Economic Impacts}

Reusing and recycling has three different economic impacts:

first, and most impotant is the reusing of glass and plastic containers which is hard to evaluate with the available data.

Second, the foreign exchange savings in the purchase of virgin materials. Virgin paper price is US\$ $150 /$ ton which means approximately a yearly total of 3 million dollars. Recycled paper can be imported at a lower price of US\$130 ton, which would lower that figure by $10 \%$. Virgin glass price is $\$ 50 /$ ton, so the yearly total saving from glass is US\$127 thousand dollars. To this have to be added all the aluminum and steel been used locally or exported abroad.

Third, savings on the disposal site are minor up to this point, given the very poor and cheap solid waste disposal practices in Costa Rica. The construction of a real sanitary landfill, probably more than 10 kilometers from the center of the metropolitan region of San José, will increase significantly those costs, to a range between US $\$ 15$ and US $\$ 25$ per ton. This change will have a very significant economic impact, for glass in particular given its lower price.

\section{Social Impacts}

In Costa Rica, "invisible sub-employment" is defined by people working more than 40 hours per week but getting very low salary. Most $\mathrm{co}^{-}$ llectors of recyclable products are probably selfemployed but receive income very similar to "in- 
visible subemployed persons" and hardly could get a better job elsewhere. The creation of powerful recycling organizations, maybe with foreign grants from non-governmental organization could destroy their old fashioned operation without increasingly significantly recovery jin not taking place or recovering very little.

The real challenge is to improve the street collectors market leverage organizing them into their own small organizations or creating non-profit alternative consolidators.

The central fact is that the focus of any nongovernmental organization trying to improve the current social situation should be people: collectors of recyclables products... not the recyclables per se.

\section{Environmental Impacts}

Environmental impacts of recycling are not very significant. Most Costa Rican recyclable materials are inert and do not represent serious health hazards. Recycling does not reduce significantly the Costa Rican waste stream, currently by only $4.8 \%$. Assuming that all the recycling takes place in the San José Metropolitan region, the recovery rate there increases to $7.1 \%$ and becomes zero for the rest of the country. Recycling and its environmental impact will increase in the following years but will be always just a small component of a bigger solution.

\section{2. ¿How much more can be recycled?}

The figures shown in Tables 4 and 5 indicate that a lot of recycling have been occurring without formal programs. They indicate also national recovery rates for paper $(22.2 \%)$ and glass $(15.5 \%)$. Those rates can be improved, but probably not as much as many environmentalist would dream. In Costa Rican urban areas recyclable products represent only $32 \%$ of the waste stream; in the United States the figure is $64 \%$.

In the United States many local governments are trying with great difficulty to reduce the waste stream by $25 \%$. To concentrate that effort only in recycling would mean to reduce the recyclables going into landfills by $39 \%$. A similar effort in Costa Rica will mean a reduction of only $12.5 \%$ of the waste stream.

The impact is even less significant in rural areas where there are no local markets for recycla- ble materials, the proportion of potential recyclable materials is only $22 \%$, that means that it is effectively impossible to reach an equivalent to the US goal (an equivalent $113 \%$ of the potentially recyclable materials).

In the non-metropolitan areas of Costa Rica to motivate separation and recycling is hard not only because the low proportion of recyclables, but also because of the lower "recyclable quality" (dirty materials, higher proportion of combined materials), the small size of towns, and the lack of local markets for the recyclable materials.

\section{Key factors in potential recycling growth}

Any strategy to increase recycling requires to define the key factors that could help or prevent advances. There are a few key factors that help to increase recovery rates:
more competitive markets at every level,
higher absolute price,
higher price to generator or street collector,
lower cost to final user compared with vir- gin material,
less geographical dispersion of the recycla- bles generators,
low collection and transportation costs from generator to final users

Besides, there is an interesting paradox for used glass: extended reuse blocks recycling economies of scale and prevents some recycling.

\section{The importance of disaggregation by product and region}

The perspectives and problems for increased recycling of paper, glass and plastic are quite different. The potential for additional recycling is also very different in different regions of the country. Important collection economies of scales, locations of markets for recycling and transportation costs to them are the key variables which mean different regional perspectives for recycling.

Paper is the most positive case, the new demand will change completely the market, will increase competition and proces. There are very good chances of increases over $100 \%$ in the recycling of paper and paperboard in the following months. 
Despite the ample market for recycled glass, this product has obviously serious problems: low prices and monopsony end user. The almost abusive profit margins of some consolidators are a clear restriction to more recycling. Prices paid to street collectors, from $\$ 3$ to $\$ 7$ per kilogram, are also extremely low compare with recycled paper's prices and with the $\$ 50$ per ton paid for virgin glass. It seems to be a real opportunity for the intervention of non-governmental institutions to reinforce the glass collection efforts and its appropriate and effective preprocessing.

Plastic has the worst recycling in Costa $\mathrm{Ri}$ $\mathrm{ca}$, but plastics markets are in transition. The new demand from final users could very soon change dramatically the situation. Plastic is the most serious "solid waste aesthetic problem", its convenience as a soft drinks container spreads its presence extensively and intrusively. The new $1.5 \mathrm{li}$ ter recoverable container promoted by Coca Cola could help to make the 2 liters container less popular and decrease somewhat the more than 100 daily tons of plastic waste.

\section{Expectations for the future}

Expected changes in the demand and economic structure of recyclable products markets, in particular paper and cardboard will increase significantly (more than $100 \%$ ) the total recycling in the San José Metropolitan Region in the following years. The increment could top easily $200 \%$ depending on the demand of the new recycling plastic factory and of market improvements for glass recycling. The latter will require institutional actions significant impact.

Outside the San José Metropolitan Region, the greatest opportunity for higher recovery rates are in the exurban highland regions to the east and west, which represent approximatly half of the non-metropolitan population. They are close to the processing plants, have good transportation links and are becoming very integrated with the metropolitan region.

In the low lands non-metropolitan regions formal recycling (almost non-existing formally, except for aluminum and some glass) will not increase significantly in the next future, unless new local uses are found for recyclable materials.

\section{Challenges and opportunities}

There are many challenges and opportunities to improve the recovery rates in Costa Rica. The following list includes some of them:

Intervention in the recycling glass markets to make it more attractive.

Creation of non-for profit recyclables consolidators focussed on improving the conditions of the street collectors and indirectly stimulating more recycling through higher prices closer to the recyclable source.

Separation and recovery at the source, specially by big generators of potentially recyclable materials (institutions, paper, and glass consumers)

- $\quad$ Creation of a few storage facilities outside the Metropolitan Region of San José, with some preprocessing capabilities to lower transportation costs to final users.

Commercial agreements with distribution companies (specially processed foods) to carry recyclables in their empty trips toward the center of the country which operates as a central distribution point for the whole nation.

To develop new technologies to use some recyclable materials locally in agricultural, agroindustry and other non-metropolitan economic activities.

\section{SOME FINAL COMMENTS}

* $\quad$ Recycling is a established tradition in Costa Rica, and recovers at least $15.5 \%$ of the glass and $22.2 \%$ of the paper waste flows within the country. This is not enough and there are great needs and opportunities for improvements.

* There is a clearly structured system of handling recyclable materials, with an informal collection system, an intermediary layer of formal consolidators wich hold monopoly power within part of the metropolitan region. On company has monopsony buying power for each material. 
* The analysis and the design of strategies for more recycling in Costa Rican requires disaggregation by product and region.

* Economic and social disparities promote the existence of street collectors and scavengers despite the collected products' very low price.

* The markets for recyclable products are not working properly and there is a chance that outside intervention from the government or non-governmental organizations could improve the competition in those markets.

* The intermediaries for paper and specially glass recycled products get extremely big profit margins.

* New end users of paper and plastic recyclables will produce big positive changes in the markets for those products.

* Education of the population on additional reuse, recycling, and solid waste separation is extremely important specially if percapita income increases and social conditions of collectors improve.

* The creation of real sanitary landfills far from the metropolitan area will increase considerable the total costs of solid waste management and will make recycling more attrative economically.

\section{REFERENCES}

1. Glysson, Eugene (sub-editor). Solid Waste. Standard handbook of Environmental Engi- neering, edited by Robert A. Corbitt, McGraw-Hill, 1990.

2. Gobierno de Costa Rica y AGencia de Cooperación Técnica de Alemania (GTZ). Plan Nacional de Manejo de Desechos Sólidos de Costa Rica. San José, Costa Rica (1991).

3. González, Minor. Diseño de un paquete tecnológico flexible para el manejo de desechos en zonas rurales. Escuela de Ingeniería Civil, Universidad de Costa Rica, 1992.

4. Instituto Costarricense de Electricidad y Electrowatt Engineering Services Ltd. Nonconventional Energy Sources. Incineration and Biomass, Volume III, December, 1985.

5. Pujol, Rosendo y Solano, Eric. Solid waste recycling in Costa Rica: now bottles for an old wine? VIII International Conference on Solid Waste Management and Secondary Materials (Proceedings). University of Pennsylvania, Philadelphia, U.S.A. (1992).

6. Solano, Eric. Determinación de los índices de generación y de la composición de los desechos sólidos. IV Congreso Nacional de Recursos Hidráulicos. San José, Costa Rica (1992).

7. U.S.Enviromental Protection Agency. Municipal Solid Waste Composition. U.S.A., 1988.

8. World Band, World Development Report 1991. Oxford University Press, 1991. 